\title{
二層流モデルによる土石流の二次元氾濫解析法 に関する研究 \\ TWO-DIMENSIONAL NUMERICAL SIMULATION MODEL FOR UNIFYING DEBRIS FLOW AND SEDIMENT SHEET FLOW
}

\author{
高濱淳一郎 1 - 藤田裕一郎 $2 \cdot$ 吉野弘祐 3 \\ Jun-ichiro TAKAHAMA, Yuichiro FUJITA and Kousuke YOSHINO
}

\begin{abstract}
1正会員 博士（工学） 岐阜大学助手 工学部社会基盤工学科（テ501-1193 岐阜県岐阜市柳戸1-1）
2正会員 工博 岐皁大学教授 流域圈科学研究せセン夕ー（テ501-1193 岐阜県岐阜市柳戸1-1)

3 学生員 岐阜大学大学院 工学部工学研究科土木工学専攻（テ501-1193 岐阜県岐阜市柳戸1-1)
\end{abstract}

\begin{abstract}
The present study deals with deposition-erosion processes of debris flow with transition between fully dispersed debris flow and sediment sheet flow. A two-layer flow model proposed by the authors was applied to twodimensional numerical simulation of debris flows, and simple numerical experiments were carried out. It was indicated that a two-dimensional numerical simulation using the two-layer flow model can analyze phenomena in which velocity directions of upper-layers of water flows are different form that of lower layers of sediment-water mixture flow.
\end{abstract}

Key Words: debris flow, two layer model, two-dimensional numerical simulation

\section{1.はじめに}

著者らは，掃流状集合流動の砂碟移動層と水流層 の構成則は本質的に異なるため，本来非定常状態に おける両層の挙動は各層の構成則を反映したものに なるべきであると考え，土石流の集合流動状態につい て，その水流層と砂啋移動層とのinterfaceを想定して， 体積保存則，運動量保存則基づいた水流層と砂礫移動層 それぞれの層の支配方程式をたてて解析する一次元計算 モデル (二層流モデル) ${ }^{1)}$ を提案した.そして，二層流 モデルを一次元水路による実験との比較を行い，全体的 な堆積侵食の傾向や堆積に伴う水流層の分離過程を再現 できることを示した2).このことは，二層流モデルは流 砂形態の区分を導入する必要がなく, 且つ砂樂移動層や 水流層の非定常流れ場を直接計算する簡潔なモデルであ るが，それによって合理的な評価が行えることを示唆し ている. 本研究では二層流モデルを水平二次元シミュ レーションに拡張する方法について説明し, 数值実験を 行った結果を述べる.

\section{2. 解析に用いた基礎方程式}

二層流モデルでは，図-1に示すように水流層と砂碟移 動層とのinterfaceを通した水流のフラックス $s_{I}$ （上向 き正）とinterfaceの速度ベクトル $\overrightarrow{u_{I}}=\left(\begin{array}{ll}u_{I} & v_{I}\end{array}\right)$ に応 じた運動量フラックスを導入して導かれる保存則に基づ いて各層毎の支配方程式が導かれている. このモデルを 水平面上に $x, y$ 軸を設定した座標系を用いて二次元に 拡張すると支配方程式は次式で示される.

$$
\begin{gathered}
\frac{\partial h_{w}}{\partial t}+\frac{\partial M_{w}}{\partial x}+\frac{\partial N_{w}}{\partial y}=s_{I} \\
\frac{\partial h_{s}}{\partial t}+\frac{\partial M_{s}}{\partial x}+\frac{\partial N_{s}}{\partial y}=s_{T}-s_{I} \\
\frac{\partial\left(c_{s} h_{s}\right)}{\partial t}+\frac{\partial\left(\gamma_{x} c_{s} M_{s}\right)}{\partial x}+\frac{\partial\left(\gamma_{y} c_{s} N_{s}\right)}{\partial y}=c_{*} s_{T} \\
\frac{\partial z_{b}}{\partial t}=-s_{T} \\
\frac{\partial M_{w}}{\partial t}+\frac{\partial\left(\beta_{w x x} u_{w} M_{w}\right)}{\partial x}+\frac{\partial\left(\beta_{w x y} v_{w} M_{w}\right)}{\partial y}-s_{I} u_{I} \\
=\frac{1}{\rho_{w}}\left\{-p_{I} \frac{\partial\left(h_{s}+z_{b}\right)}{\partial x}-\frac{\partial P_{w}}{\partial x}-\tau_{w x}\right\}
\end{gathered}
$$




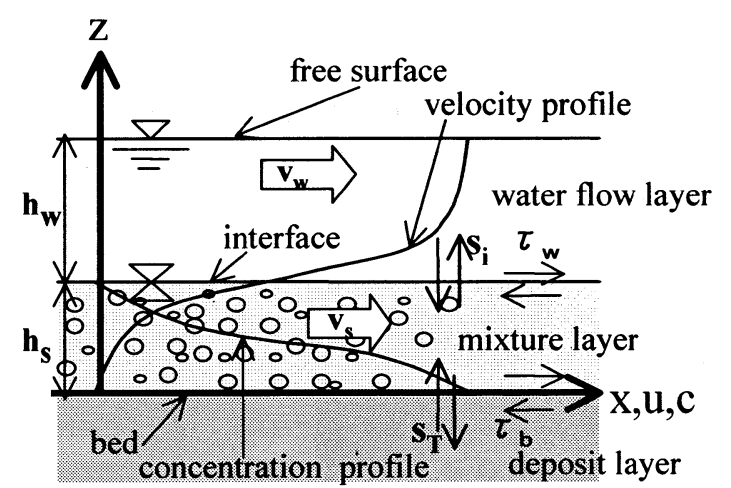

図-1 二層流モデルの模式図

$$
\begin{aligned}
& \frac{\partial N_{w}}{\partial t}+\frac{\partial\left(\beta_{w x y} u_{w} N_{w}\right)}{\partial x}+\frac{\partial\left(\beta_{w y y} v_{w} N_{w}\right)}{\partial y}-s_{I} v_{I} \\
& =\frac{1}{\rho_{w}}\left\{-p_{I} \frac{\partial\left(h_{s}+z_{b}\right)}{\partial y}-\frac{\partial P_{w}}{\partial y}-\tau_{w y}\right\} \\
& \frac{\partial\left(\gamma^{\prime} \rho_{s} M_{s}\right)}{\partial t}+\frac{\partial\left(\beta_{s x} \rho_{s} u_{s} M_{s}\right)}{\partial x}+\frac{\partial\left(\beta_{s x y} \rho_{s} v_{s} M_{s}\right)}{\partial y} \\
& +\rho_{w} s_{I} u_{I} \\
& =-p_{b} \frac{\partial z_{b}}{\partial x}+p_{I} \frac{\partial\left(h_{s}+z_{b}\right)}{\partial x}-\frac{\partial P_{s}}{\partial x}+\tau_{w x}-\tau_{b x} \\
& \frac{\partial\left(\gamma^{\prime} \rho_{s} N_{s}\right)}{\partial t}+\frac{\partial\left(\beta_{s x y} \rho_{s} u_{s} N_{s}\right)}{\partial x}+\frac{\partial\left(\beta_{s y y} \rho_{s} v_{s} N_{s}\right)}{\partial y} \\
& +\rho_{w} s_{I} v_{I} \\
& =-p_{b} \frac{\partial z_{b}}{\partial y}+p_{I} \frac{\partial\left(h_{s}+z_{b}\right)}{\partial y}-\frac{\partial P_{s}}{\partial y}+\tau_{w y}-\tau_{b y}
\end{aligned}
$$

ここに，添え字の $s, w$ はそれぞれ砂礫移動層と水流層 に関する物理量を示し, $M=u h, N=v h, u, v$ はそ れぞれ $x$ 方向, $y$ 方向の砂砅移動層あるいは水流層の層 平均流速, $h$ は各層の流動層厚, $\rho$ は各層の層平均密 度，P は各層についてその層厚に渡って積分した圧力 である。 また， $p_{I} ， p_{b}$ はそれぞれinterfaceにおけ る圧力, 河床における圧力， $c_{s}, c_{*}$ はそれぞれ砂碟移 動層平均濃度, 停止堆積層濃度, $z_{b}$ は河床高, $s_{T}$ は侵 食速度である. $\tau_{w x}, \tau_{w y}$ はそれぞれinterfaceにおけ るせん断応力の $\mathrm{x}$ 方向成分と $\mathrm{y}$ 方向成分であり, $\tau_{b x}$, $\tau_{b y}$ はそれぞれ河床面せん断応力の $\mathrm{x}$ 方向成分と $\mathrm{y}$ 方向成 分である. また, $\gamma, \gamma^{\prime}, \beta$ は流速と濃度の分布に基 づく補正係数であるが，以下の解析ではすべて 1 とした。 解析にあたっては一次元モデルに採用した一様濃度近似 1)2) を導入し，河床面せん断応力とinterfaceにおけるせ ん断応力は江頭らの構成則 ${ }^{3}$ を一様濃度に適用したもの を用い，侵食速度は江頭らの侵食速度式) を二層流に拡 張したものを用いる ${ }^{122)}$ ．なお，本研究では，以前の近似 解に導入していた近似と仮定 ${ }^{12)}$ を以下のように若干修正 する.

(1)砂䂺移動層濃度は一样濃度 $\left(c_{s}=c_{*} / 2\right)$ とする ${ }^{12)}$. (2)河床面では粒子衝突に伴う圧力 $p_{d}$ とゼロとする ${ }^{122)}$. これにより，平衡状態における河床面の応力は近似解と
厳密解とで一致する. 流動層内では $p_{d}$ と骨格応力 $p_{s}$ と の比を一定 ${ }^{122)}$ とせず, 濃度の関数 ${ }^{3)}$ として $p_{s} /\left(p_{s}+p_{d}\right)=\left(c_{s} / c_{*}\right)^{1 / 5}$ で与える.

(3)门によって計算される砂碩移動層厚が全流動層厚より 大きくなるときは, 流れの全層が砂砂移動層として取り 扱う。このとき, $c_{s} \geq c_{*} / 2$ となる。

(4)砂碑移動層の流速分布形や砂碑移動層の抵抗係数を算 出する際に流動層内で降伏応力が外力を上回る場合は, 外力を補正していた ${ }^{12}{ }^{2}$ が, 本研究では全層平均濃度 $c_{t}$ に対応する平衡勾配を用いて抵抗俰数を計算する. これ は, 宮本 ${ }^{5}$ らが江頭らの構成則 ${ }^{3}$ を用いて非定常流れ場に おいて降伏応力が外力（駆動力）を上回るような領域に 対しても河床面せん断応力を合理的に評価するために提 案した方法と一致する. 後述するように, 江頭ら ${ }^{3)}$ の構 成則に基づく河床面せん断応力中の抵抗係数を評価する 際に, 土石流の平衡状態における河床面での外力と降伏 応力との釣り合い式を用いている.

二次元化された二層流支配方程式に基づいて解析する ためには, 砂磼移動層と水流層の流向が異なる流れ場を 取り扱う必要が生じる. ここでは, 以下に示すような評 価法を導入した. interfaceに作用するせん断応力の $\mathrm{x}, \mathrm{y}$ 方向成分 $\tau_{w x}, \tau_{w y}$ については, 両層の平均流速方向の 差異を考慮するため, 次式のように与えることとした.

$$
\begin{gathered}
\tau_{w x}=\rho_{w} f_{w}\left(u_{w}-u_{I}\right) \sqrt{\left(u_{w}-u_{I}\right)^{2}+\left(v_{w}-v_{I}\right)^{2}} \\
\tau_{w y}=\rho_{w} f_{w}\left(v_{w}-v_{I}\right) \sqrt{\left(u_{w}-u_{I}\right)^{2}+\left(v_{w}-v_{I}\right)^{2}}
\end{gathered}
$$

interfaceの流速 $u_{I}, v_{I}$ は一次元流れの場合と同様に砂 砅移動層の流速分布形に基づいて計算している. また, $f_{w}$ は江頭らによる水流層の構成則 ${ }^{3}$ を一様濃度 $c_{s}$ に適 用した抵抗係数であり, 次式で与えられる.

$$
\begin{aligned}
f_{w} & =\left[\frac{1}{\kappa}\left\{\left(1+\frac{\eta_{0}}{h_{w}}\right) \ln \left(1+\frac{h_{w}}{\eta_{0}}\right)-1\right\}\right]^{-2} \\
\eta_{0} & =\sqrt{k_{f}}\left\{\left(1-c_{s}\right) / c_{s}\right\}^{1 / 3} d
\end{aligned}
$$

ここに， $\kappa$ はカルマン定数， $k_{f}$ は実験定数で $0.16 〜$ $0.25, d$ は砂粒子径である.

一方, 河床面せん断応力は, 降伏応力と流動応力との 和として次式のように与える.

$$
\begin{gathered}
\tau_{b x}=\tau_{y} \frac{u_{s}}{\sqrt{u_{s}^{2}+v_{s}^{2}}}+\rho_{w} f_{s} u_{s} \sqrt{u_{s}^{2}+v_{s}^{2}} \\
\tau_{b y}=\tau_{y} \frac{v_{s}}{\sqrt{u_{s}^{2}+v_{s}^{2}}}+\rho_{w} f_{s} v_{s} \sqrt{u_{s}^{2}+v_{s}^{2}}
\end{gathered}
$$

ここで，降伏応力 $\tau_{y}$ は先に示した修正した近似(2)基 づいて, 河床面の最急勾配 $\theta_{\text {max }}$ を用いて次式のように 与えている. 
$\tau_{y}=\left(\sigma-\rho_{w}\right) c_{s} g h_{s}\left(\frac{c_{s}}{c_{*}}\right)^{1 / 5} \cos \theta_{\max } \tan \phi$

ここに， $\phi$ は砂碟の内部摩擦角である. また，抵抗係数 $f_{s}$ は同じく(4)で示した方法に基づき次式のように与え ている.

•) $\widetilde{G}_{y k} \neq 0$

$$
f_{s}=\frac{\widetilde{W}+\widetilde{G}_{y k}}{\frac{4}{9} \frac{1}{f\left(c_{s}\right)} \frac{1}{\tilde{G}_{u k}{ }^{2}}\left[\left(\tilde{W}+\tilde{G}_{y k}\right)^{2}+\frac{2}{5} \frac{1}{\tilde{G}_{y k}}\left\{\hat{T}^{5 / 2}-\left(\tilde{W}+\tilde{G}_{y k}\right)^{2}\right\}^{2}\right.}\left(\frac{h_{s}}{d}\right)^{-2}
$$

-) $\widetilde{G}_{y k}=0$

$$
f_{s}=4 f\left(c_{s}\right)\left(\frac{h_{s}}{d}\right)^{-2}
$$

ここに，

$$
\begin{aligned}
\widetilde{W}= & -\left\{\left(\sigma / \rho_{w}-1\right) c_{s}+1\right\} \sin \tilde{\theta}_{e} \\
& +\left(\sigma / \rho_{w}-1\right) c_{s} \cos \tilde{\theta}_{e} \tan \phi \\
\tilde{G}_{y k}= & \left\{\left(\sigma / \rho_{\mathrm{w}}-1\right) c_{s}+1\right\} \sin \tilde{\theta}_{e} \\
& -\left(\sigma / \rho_{\mathrm{w}}-1\right) c_{s} \cos \tilde{\theta}_{e}\left(c / c_{*}\right)^{1 / 5} \tan \phi_{s} \\
f\left(c_{s}\right)= & k_{f}\left\{\left(1-c_{s}\right)^{5 / 3} / c_{s}^{2 / 3}\right\}+k_{g}\left(\sigma / \rho_{w}\right)\left(1-e^{2}\right) c_{s}^{1 / 3} \\
\tan \tilde{\theta}_{e}= & \frac{\left(\sigma / \rho_{w}-1\right) c_{t}}{\left(\sigma / \rho_{w}-1\right) c_{t}+1} \tan \phi
\end{aligned}
$$

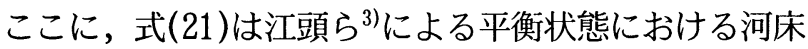
面での外力（駆動力）と降伏応力との釣り合い式から導 かれる. また， $k_{g}$ は経験定数で $k_{g}=0.0828, e$ は砂礫 の反発係数である.

侵食速度式は次のようにして二次元に拡張した．まず， 一次元モデルにおける侵食堆積速度式は次式で与えられ ている1223).

$$
s_{T}=\left|v_{t}\right| \tan \left(\theta_{f d}-\theta_{e}\right)
$$

ここに， $v_{t}$ は二層流全体の平均流速， $\theta_{e}$ は全層平均濃 度 $c_{t}$ に対応する平衡勾配であり,一次元流れに対しては 全流動層厚を $h_{t}$ 用いてそれぞれ以下のように与えてい た。

$$
\begin{aligned}
& v_{t}=\frac{M_{s}+M_{w}}{h_{t}} \\
& \tan \theta_{e}=\frac{\left(\sigma / \rho_{\mathrm{w}}-1\right) c_{t}}{\left(\sigma / \rho_{\mathrm{w}}-1\right) c_{t}+1} \tan \phi \\
& c_{t}=c_{s} \frac{h_{s}}{h_{t}}
\end{aligned}
$$

ここでは式 (22)を二次元流れ場に拡張するため， $v_{t}$ の 流向を砂碟移動層の流向に一致させることとし, 砂碟移 動層と水流層の流下方向が異なることを考慮して，砂礫 移動層の流下方向に見た勾配を $\theta_{f d}$ とし， $v_{t}$ は水流層の
フラックスの砂碟移動層流向成分と砂㦡移動層のフラッ クスとの和を流れ全体の流動層厚 $h_{t}$ で除して与えた。

$v_{t}=\frac{\left(\overrightarrow{M_{w}} \cdot \overrightarrow{e_{s}}+\left|\overrightarrow{M_{s}}\right|\right)}{h_{t}}$

ここに, $\overrightarrow{M_{w}}, \overrightarrow{M_{s}}$ はそれぞれ水流層, 砂碟移動層の フラックスベクトル， $\overrightarrow{e_{s}}$ は砂砅移動層の平均流速方向 の単位べクトルである.

さらに, 砂碟移動層の停止と再移動を判断・評価する ために, 宮本 ${ }^{6}$ が土塊の運動の二次元シミュレーション 計算において提案した方法を準用した。宮本 $\left.{ }^{6}\right)$ は, 支配 方程式（運動方程式）を差分化して数値的に土塊の運動 を解析するとき，土塊の停止は一般に差分時間内に現れ るため，その時間を知るために差分化した支配方程式を 基に土塊の停止条件を与えている. 土塊の停止条件は土 塊の運動量べクトルがゼロベクトルになることで与えら れるため, 二次元場でのべクトル方程式を解くことにな る. しかし, 圧力勾配ベクトルは土塊の運動量ベクトル とは互いに一次独立にあるため, 運動量べクトルがゼロ ベクトルになるためには水面勾配ベクトルがゼロベクト ルであるという物理的に意味のない条件下で解が存在す ることが宮本 ${ }^{6}$ によって指摘されている. そこで，宮本 ${ }^{6)}$ は停止条件式に近似を導入することで停止条件を与えて いる．この宮本による方法を以下のように二層流に適用 した.まず, 砂衒移動層の運動方程式(7)(8)を固体摩擦 応力に着目して差分時間を $\Delta t$ として時間差分すれば次 式のようになる。

$$
\left(\begin{array}{l}
\left(\rho_{s} M_{s}\right)_{i}^{+\Delta t} \\
\left(\rho_{s} N_{s}\right)_{i}^{++\Delta t}
\end{array}\right)=\left(\begin{array}{l}
\left(\rho_{s} M_{s}\right)_{i} \\
\left(\rho_{s} N_{s}\right)_{i}^{j}
\end{array}\right)+\left(\begin{array}{l}
F_{x} \\
F_{y}
\end{array}\right) \Delta t-\left(\begin{array}{l}
\tau_{y x} \\
\tau_{y y}
\end{array}\right) \Delta t
$$

ここに， $\tau_{y x}, \tau_{y y}$ はそれぞれ降伏応力 $\tau_{y}$ の $x, y$ 方向成 分であり, $F_{x x}, F_{y}$ はぞれぞれ次式で与えられる.

$$
\begin{aligned}
F_{x}= & -\frac{\partial \rho_{s} u_{s} M_{s}}{\partial x}-\frac{\partial \rho_{s} v_{s} M_{s}}{\partial y}-\rho_{w} s_{I} u_{I} \\
& -p_{b} \frac{\partial z_{b}}{\partial x}+p_{I} \frac{\partial\left(h_{s}+z_{b}\right)}{\partial x}-\frac{\partial P_{s}}{\partial x}+\tau_{w x}-\tau_{b D x} \\
F_{y}= & -\frac{\partial \rho_{s} u_{s} N_{s}}{\partial x}-\frac{\partial \rho_{s} v_{s} N_{s}}{\partial y}-\rho_{w} s_{I} v_{I} \\
& -p_{b} \frac{\partial z_{b}}{\partial y}+p_{I} \frac{\partial\left(h_{s}+z_{b}\right)}{\partial y}-\frac{\partial P_{s}}{\partial y}+\tau_{w y}-\tau_{b D y}
\end{aligned}
$$

ここに, $\tau_{b D x}, \tau_{b D y}$ はそれぞれ式(13)(14)中の流動応力 の $x, y$ 成分である.

ここで,宮本の用いた近似6)導入し，次式を満たす実 根 $\Delta t^{\prime}$ が $0<\Delta t^{\prime} \leq \Delta t$ の範囲にあることを停止条件とし た。 


$$
\begin{aligned}
& \left|\left(\begin{array}{c}
\left(\rho_{s} M_{s}\right)_{i}^{t+\Delta t^{\prime}} \\
\left(\rho_{s} N_{s}\right)_{i}^{t+\Delta t^{\prime}}
\end{array}\right)\right|=\left|\left(\begin{array}{c}
\left(\rho_{s} M_{s}\right)_{i}^{t} \\
\left(\rho_{s} N_{s}\right)_{i}^{t}
\end{array}\right)+\left(\begin{array}{c}
F_{x} \\
F_{y}
\end{array}\right) \Delta t^{\prime}\right|-\left|\tau_{y}\right| \Delta t^{\prime} \\
& \equiv\left|\left(\begin{array}{l}
\left(\rho_{s} M_{s}\right)_{i}^{t+\Delta t} \\
\left(\rho_{s} M_{s}\right)_{i}^{t+\Delta t}
\end{array}\right)\right|-\left|\tau_{y}\right| \Delta t^{\prime}=0
\end{aligned}
$$

式(30)では, 降伏応力以外の力積によって変化する砂磁 移動層の運動量ベクトルの絶対值が降伏応力による力積 の絶対值以下になれば停止することを意味している．宮 本の方法では，土塊が時刻 $t+\Delta t^{\prime}$ でいったん停止しても， そのまま停止し続けるかを再度チェックしているが, こ こでは簡単のため, 時刻 $t+\Delta t$ で砂砅移動層が停止した 場合，時刻 $t+\Delta t$ まで停止し続けるものとする. そして, 次の計算ステップにおいて土塊に作用する力が降伏応力 を上回る条件，すなわち次式を満足するときに砂礫移動 層が再移動するものとした.

$$
\left|\left(\begin{array}{l}
F_{0 x} \\
F_{0 y}
\end{array}\right)\right|>\left|\tau_{y}\right|
$$

ここで，再移動を判断する際の $\tau_{y}$ には宮本 $\left.{ }^{6}\right)$ と同様に最 大静止摩擦力を与えている. また, $F_{0 x}, F_{0 y}$ は停止時 における砂䃇移動層に作用寸る力であり, 次式で与えら れる.

$$
\begin{aligned}
F_{0 x}= & -\frac{\partial \rho_{s} u_{s} M_{s}}{\partial x}-\frac{\partial \rho_{s} v_{s} M_{s}}{\partial y} \\
& -p_{b} \frac{\partial z_{b}}{\partial x}+p_{I} \frac{\partial\left(h_{s}+z_{b}\right)}{\partial x}-\frac{\partial P_{s}}{\partial x}+\tau_{w x} \\
F_{0 y}= & -\frac{\partial \rho_{s} u_{s} N_{s}}{\partial x}-\frac{\partial \rho_{s} v_{s} N_{s}}{\partial y} \\
& -p_{b} \frac{\partial z_{b}}{\partial y}+p_{I} \frac{\partial\left(h_{s}+z_{b}\right)}{\partial y}-\frac{\partial P_{s}}{\partial y}+\tau_{w y}
\end{aligned}
$$

式(31)の条件を満たすとき, 再移動した砂碟移動層の運 動量を次式のように与える.

$$
\begin{aligned}
& \left(\begin{array}{l}
\left(\rho_{s} M_{s}\right)_{i}^{t+\Delta t} \\
\left(\rho_{s} N_{s}\right)_{i}^{t+\Delta t}
\end{array}\right)=\left[\left(\begin{array}{l}
F_{0 x} \\
F_{0 y}
\end{array}\right)-\left|\tau_{y}\right|\left(\begin{array}{l}
e_{s x} \\
e_{s y}
\end{array}\right)\right] \Delta t \\
& \left(\begin{array}{l}
e_{s x} \\
e_{s y}
\end{array}\right)=\frac{1}{\sqrt{{F_{0 x}{ }^{2}+F_{0 y}^{2}}^{2}}\left(\begin{array}{l}
F_{0 x} \\
F_{0 y}
\end{array}\right)}
\end{aligned}
$$

式(34) は降伏応力が土塊に作用する駆動力と逆向きに作 用することを意味している.

\section{3. 数值実験結果}

まず，図-2の等高線鳥瞰図に示すような固定床水路を 有する二つ折れの固定床斜面（上流側 $18^{\circ}$ ，下流側 $4^{\circ}$ ）の上流端から一定濃度 $30 \%$ の石流を単位幅あたり

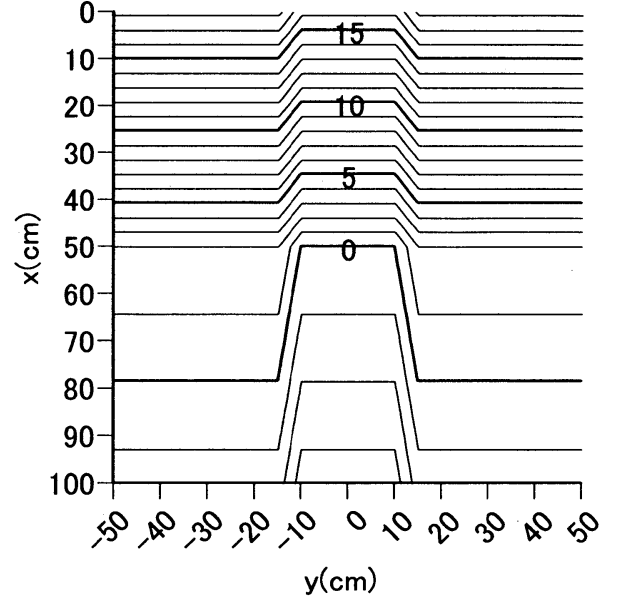

図-2 固定床水路を有する固定床斜面の等高線図 (等高線間隔は $1 \mathrm{~cm}$ )

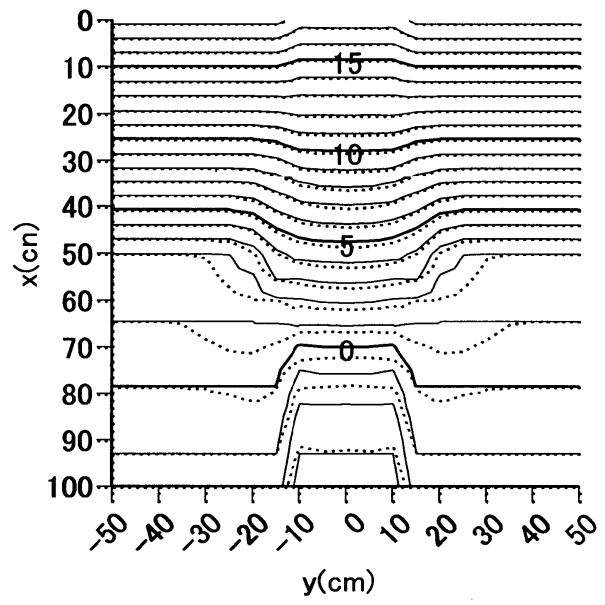

図-3 5秒後の砂䂹移動層表面標高（実線）と 自由表面標高（点線）に関する等高線図

(等高線間隔は $1 \mathrm{~cm}$ )

$70 \mathrm{~cm}^{2} / \mathrm{s}$ で幅 $20 \mathrm{~cm}$ に渡って定常供給する条件で数值実験 を行った. 固定床水路底部の幅は $20 \mathrm{~cm}$ であり, 低部標高 は左右斜面の標高より $2 \mathrm{~cm}$ 低くなっている，また，標高 $2 \mathrm{~cm}$ の地点が斜面の勾配急減位置である. メッシュサイ ズは $5 \mathrm{~cm}$ し, 供給した土砂の粒径は $0.2 \mathrm{~cm}$ である. 供給 開始から 5 秒後の計算結果の等高線図を図-3に示寸. 図 から分かるように緩勾配域へ流入した土石流が堆積し， 分離した水流は水路内を流下寸る一方で, 水路からあふ れて下流へと流下している状況が計算されている.

つぎに，図-4の等高線図に示寸ような二つ折れの飽和 移動床斜面（上流側 $18^{\circ}$ ，下流側 $4^{\circ}$ ，河床材料の粒径 は0. $5 \mathrm{~cm}$ ) の上流端中央部 $($ 幅 $20 \mathrm{~cm}$ ) から一定流量 (単位幅 あたり $100 \mathrm{~cm}^{2} / \mathrm{s}$ ) の清水を一定時間(10秒間)給水する条 件で数值実験を行った。メッシュサイズは $2 \mathrm{~cm}$, 侵食可 能深は $5 \mathrm{~cm}$ に設定してある. 図-5, 6, 7,8には砂砂移動層 表面 (interface) 標高，および自由表面標高，の等高線 図の時間的変化 (2秒後, 6秒後, 12秒後, および18秒後) が示してある. 同図では $10 \mathrm{~cm}$ ピッチで出力した計算結果 に対応している. また，図-9は最終河床形状に関する等 高線図であり，全計算点の出力結果に対応している. 図 


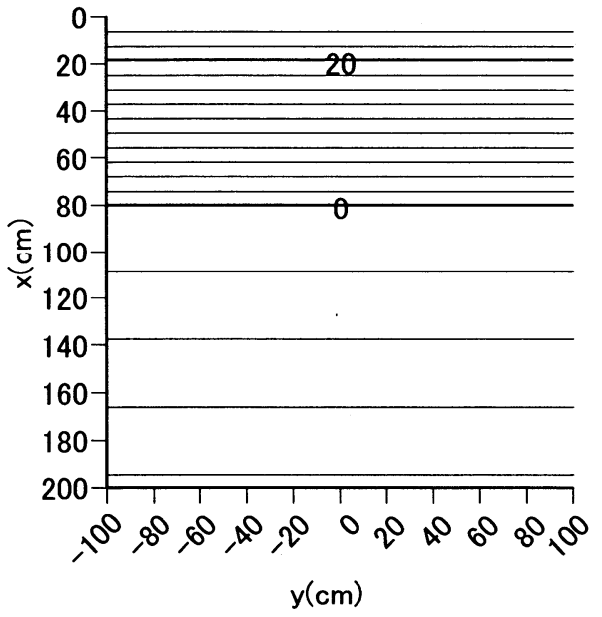

図-4 飽和移動斜面の初期形状に関する等高線図

(等高線間隔は $2 \mathrm{~cm}$ )

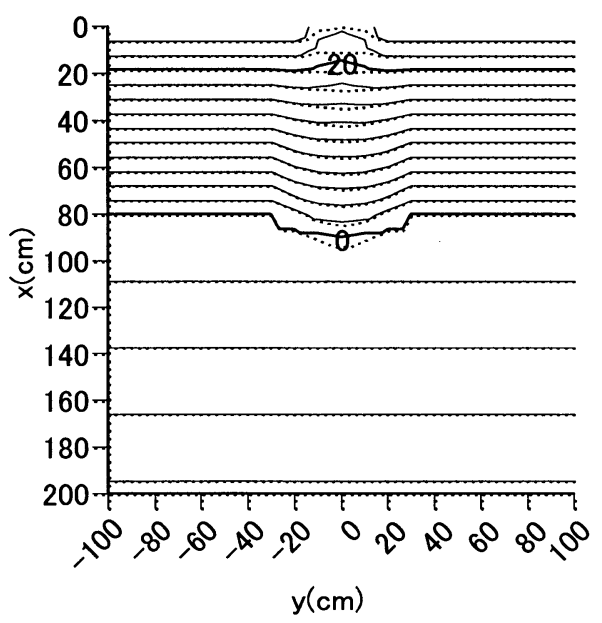

図-5 2秒後の砂碩移動層表面標高（実線）と 自由表面標高に関寸る等高線図 (等高線間隔は2 $\mathrm{cm}$ )

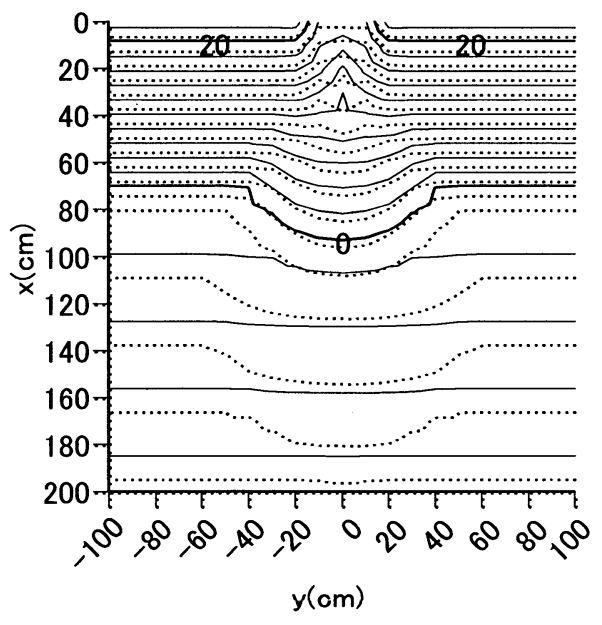

図-6 6秒後の砂制移動層表面標高（実線）と 自由表面標高に関する等高線図 (等高線間隔は $2 \mathrm{~cm}$ )

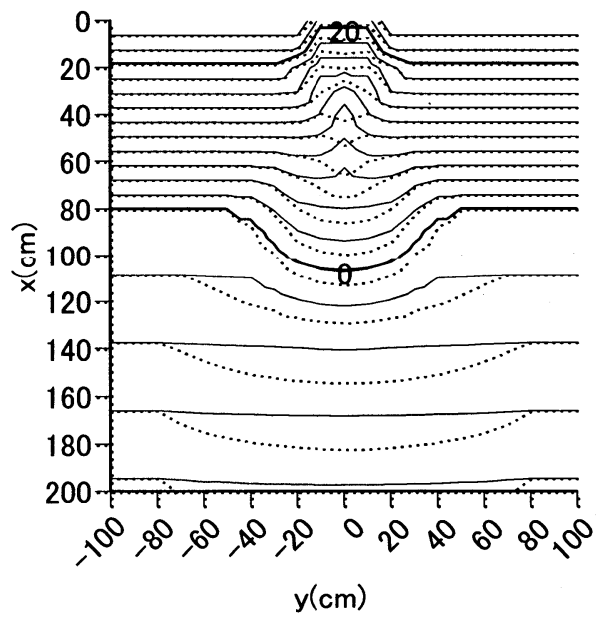

図-7 12秒後の砂砶移動層表面標高（実線）と 自由表面標高に関する等高線図 (等高線間隔は $2 \mathrm{~cm}$ )

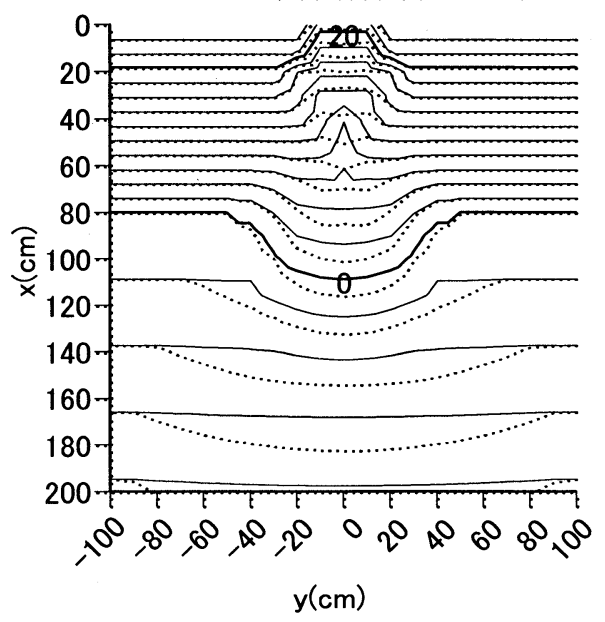

図-8 18秒後の砂磞移動層表面標高（実線）と 自由表面標高に関する等高線図 (等高線間隔は $2 \mathrm{~cm}$ )

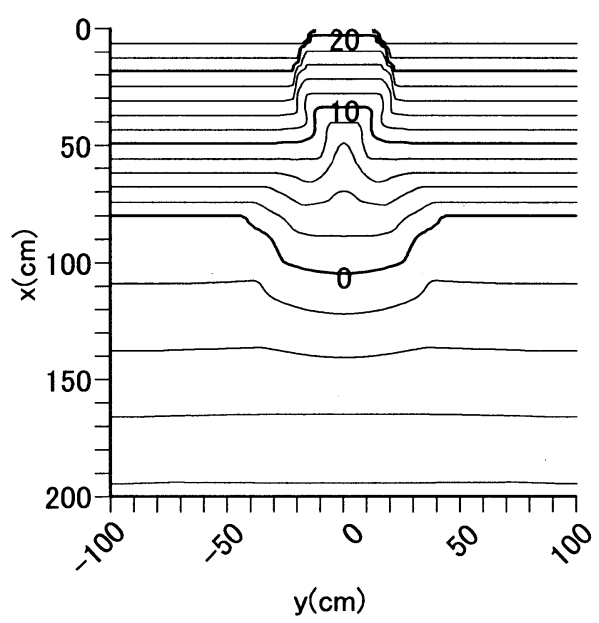

図-9 最終河床形状に関する等高線図 (等高線間隔は $2 \mathrm{~cm}$ ) 
から分かるように上流端近傍では侵食可能深まで侵食が 進行しており，固定床が露出していろ，下流側では堆皘 汇濫が生じており, 一次元モデルの場合と同様に堆積に 伴う水流層の分離が表現されている. また，上流側で固 定床が露出することに伴い下流への供給土砂濃度が減少 するため, 堆積部の上部にみずみちが形成されているこ とがわかる. 以上の結果は，本モデルによって両層の非 定常性や流向の差異を考慮した解析が可能であることを 示唆している.

\section{4.おわりに}

二層流モデルを土石流の二次元汇濫シミュレーション に拡張し, 簡単な数值実験を行って考察を加えた. 数值 実験の結果, 流路に土石流が堆積し, 流水（泥水）が流 路から溢れて汇濫するような現象や，低濃度の土砂や流 水の供給によって堆積の上部にみずみちが形成されるこ とを表現できることなどが確認された。すなわち，下層 の砂碟移動層と上層の水流層とで流下方向が異なる流れ 場においても本モデルでは解析が可能であることが示唆 された. 今後, 二次元化にあたって導入した評価法につ
いて詳しく議論するとともに水路実験との比較検討を 行っていきたい.

\section{参考文献}

1) 高濱淳一郎・藤田裕一郎・近藤康弘 : 土石流加掃流状集合 流動へ遷移する流れの解析法に関する研究, 水工学論文集, 第44巻, pp.683-686, 2000.

2) 高濱淳一郎・藤田裕一郎・近藤康弘・蜂谷圭 : 土石流の堆積 侵食に関する実験と二層流モデルによる解析，水工学論文集， 第46巻, pp.677-682, 2002.

3) 江頭進治・宮本邦明・伊藤隆郭 : 掃流砂量に関する力学的解 釈, 水工学論文集, 第41巻, pp.789-794,1997.

4) 江頭進治・芦田和男・佐々木浩 : 土石流の流動機構, 第32回 水理講演会論文集, pp.485-490, 1988.

5) 宮本邦明・伊藤隆郭 : 支配方程式に侵食速度式を導入した場 合の土石流の数值シミュレーション手法, 砂防学会誌, Vol.55, №2, pp.24-35, 2002.

6) 宮本邦明 : 土塊の運動の二次元シミュレーション, 砂防学会 誌, Vol.55, No.2, pp.5-13, 2003.

(2003.9.30受付) 